\title{
Products Branding and Online Shopping Sites Branding on Internet by Online Media Broadcasters
}

\author{
I Rahmadi ${ }^{1}$, T Fidowaty ${ }^{2}$ \\ \{ilham.rahmadi@mahasiswa.unikom.ac.id ${ }^{1}$, tatik.fidowaty@email.unikom.ac.id² $\}$ \\ Department of Communication Studies ${ }^{1}$, Department of Government Science ${ }^{2}$, Universitas \\ Komputer Indonesia, Bandung,Indonesia

\begin{abstract}
The purpose of this study is to find out the branding carried out by online media broadcasters between online shopping sites and products, and thus to find out the benefits of using online media broadcasting services. The method used in this study was the descriptive method, namely by presenting a complete picture of the situation related to some of the situation variables being studied. The results obtained from this study are that many publishers who do branding are broadcasters who already have many viewers, and the purpose of this branding is to increase product sales and increase online shopping site visitors. From these results it was found that online shopping products and sites are products and online shopping sites for teens to adults. This is because online media broadcasters are young and mature, and thus the audience is still young. besides that the contents and web design are the main attraction for site visitors or buyers. However, more important is the design and benefits of the product. The use of so many social media is also one of the factors that make online sales grow rapidly. In conclusion, branding can influence product buying interest and interest in visiting online shopping sites.
\end{abstract}

Keyword : Online Shopping, Social Media, Promotion.

\section{Introduction}

Lakshmi and Dr.Mutumani explained that brand strength is formed through brand awareness. It is all about making consumers familiar about their products and services.[1] In addition, Web content has been identified as one of the main factors contributing to repeated visits. Because content on the web includes text, images, graphics, layout, sound, movement and, one day, even smells, making the right web content decisions is very important for effective web design[2]. So business development in the field of technology largely results from synergies between creative idea owners (technopreneur), who are generally affiliated with various research centres (such as universities), with providers of capital to be used in doing business[3.]

With the help of the internet, consumers can find a lot of information they need about goods and services provided by other consumers or to share their opinions and experiences of using goods and services with many other consumers[4.] There are definite pros and cons to happen when researchers believe that social media provides a unique opportunity for brands to improve good relationships with customers, while some of them disagree with this[5]. As written by Chung, Christina; Austria, Kristine, entitled Social Media Gratification and Attitude toward Social Media Marketing Messages: A Study of the Effect of Social Media Marketing Messages on Online Shopping Value[6].

The increasing popularity of social media such as Facebook and Twitter creating a new delivery platform in e-commerce is called social trade Also social media platforms like Twitter and Facebook allow the creation of virtual customer environments where engaged online communities are formed around a particular company, brand, or product[7]. Departing from this, social media has provided new opportunities for consumers to involve social interaction on the internet[8]. Consumers use social media, such as online communities, to produce content and networks with other users.[9]

E-commerce is currently used not only in sales such as clothing, household appliances, 
accessories, but business people are starting to use e-commerce to sell various tickets and hotel reservations[10]. There is paid promotion and support is one example of how to promote on social media with the internet. Having lots of followers on social media is one of the considerations that products or services sold will be promoted through social media account services. Now social media is not only used as a media campaign with the internet but has become a business that can make money. In the end branding is useful for building brand awareness. Branding is not just to build brand awareness; branding is also useful to promote anything that carries an identity [11].

\section{Material and Methods}

This research used descriptive method to find out the variables related to e-commerce and branding on social media and previous research related to the development of e-commerce and branding through social media. So it could analyse how much the influence of branding on social media in the e-commerce business world.

\section{Results and Discussion}

To introduce a product and give it a brand, online media broadcasters insert scenes for a few seconds to introduce the product and to be given a branding. Online media broadcasters usually insert this scene at the beginning of the video to show a company that has sponsored the video.

It can be seen below is the scene of broadcasters who already did the branding of a product. Shown in Fig 1.

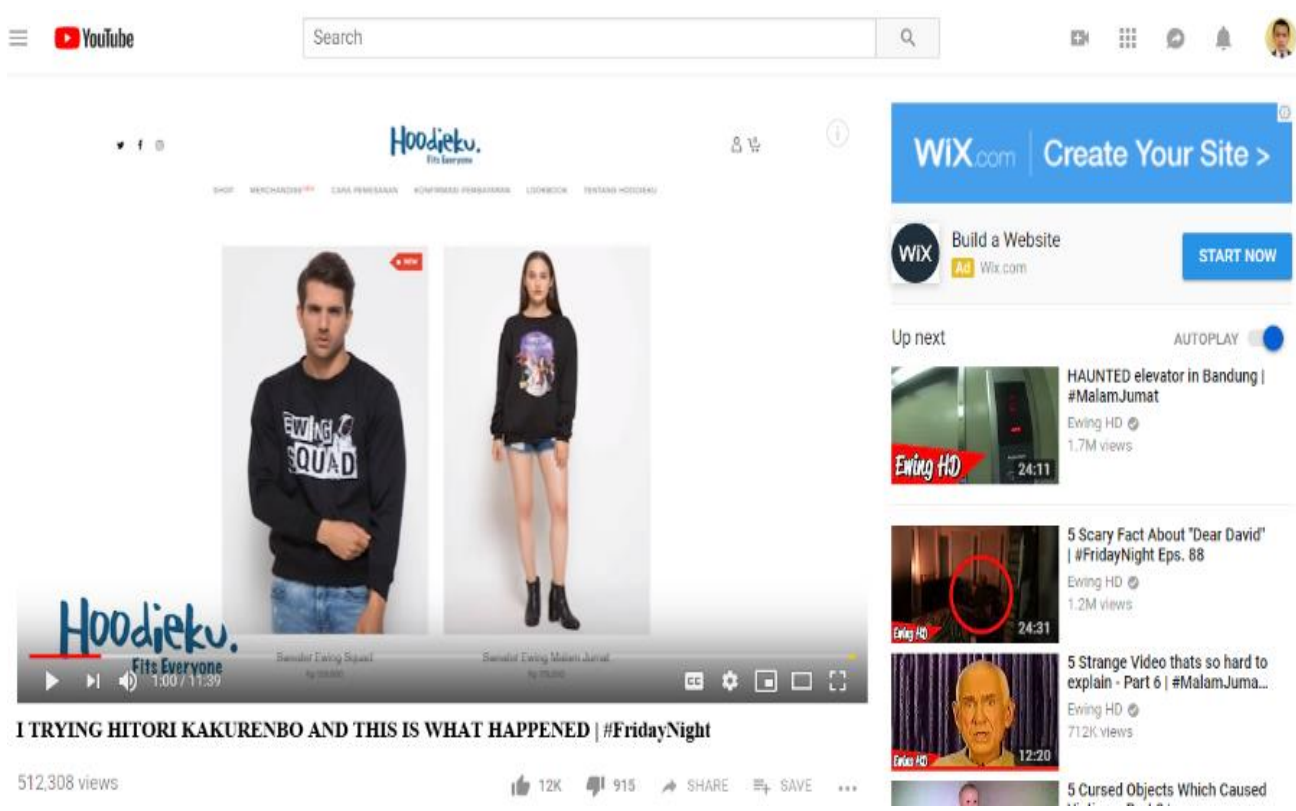

Fig 1. Branding by Ewing HD, this figure was adopted from www.youtube.com on November 27, 2018.

In the early minutes of a video, the broadcaster is seen displaying an online shopping website that sponsoring the video. So the audience can find out a product introduced by the broadcaster. Not only shown through the video, also the video is including the website address by the broadcaster in the description. Shown in Fig 2. 


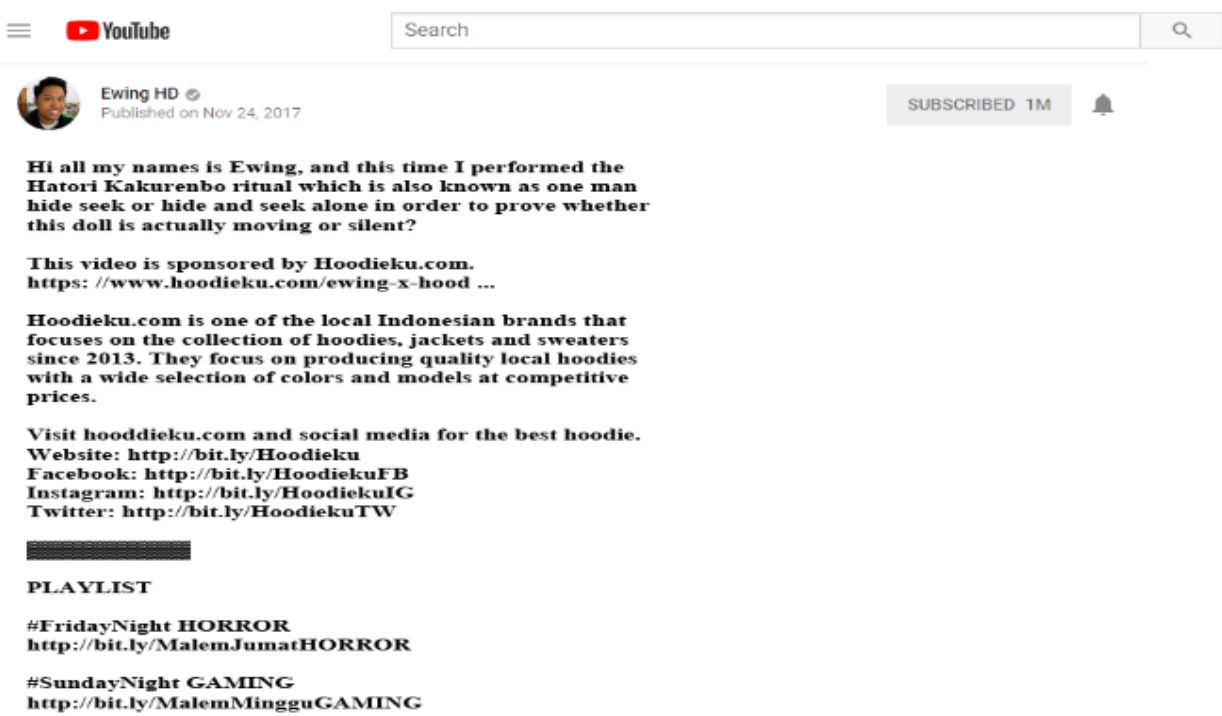

Fig 2. Video Description of Figure 1, this figure was adopted from www.youtube.com on November 27, 2018.

The figure above shows a description of the videos were being displayed, like an introduction to what was shown on the video. Not only that, in the description of the video the broadcaster included the address of the online shopping website that was already branding by the broadcaster, also the broadcaster explained that the video was sponsored by the product were branding by him. After looking at the description of the video, and then its time to visit the address of the online shopping website by clicking on the web address in the description, here it is the view of the online shopping site that was branded by the broadcaster. Shown in Fig 3.

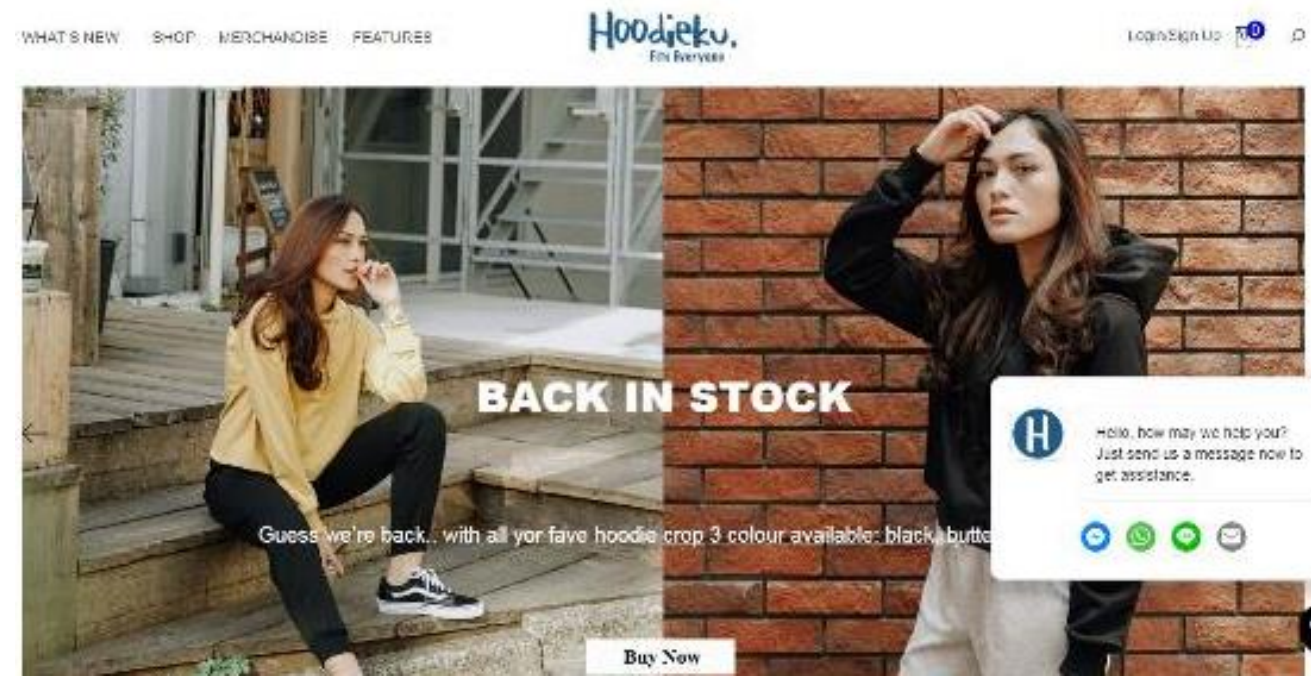

Fig 3. The figure of website in video description.

The online shopping site sells various models of sweaters for teenager. The channel above (Figure 2) which is often seen by teenager makes this company choose the broadcaster to do the branding of their products because is suitable with the target market desired by the company. Below is another example of a branding carried out by a streamer. This time the broadcaster who carried out the branding was an international broadcaster who had been known for his career as an international broadcaster shown in Fig 4. 


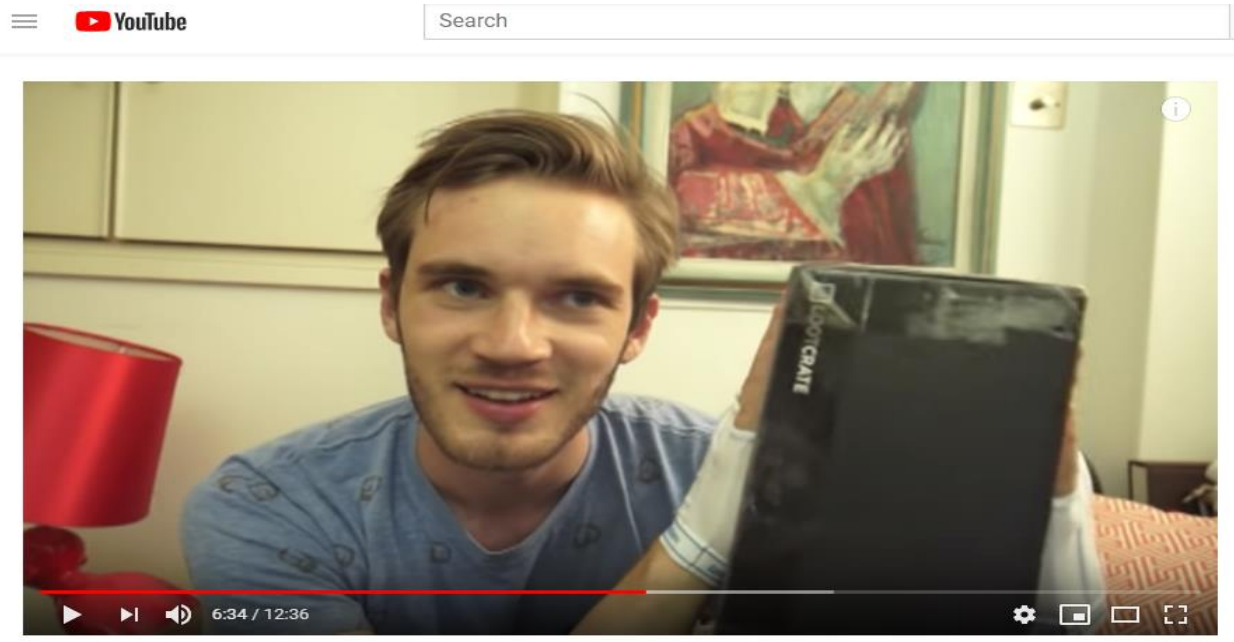

The Worlds Most Powerful Handheld Laser! (5 Weird Stuff Online - Part 14)

$13,005,309$ views

$$
\text { If } 484 \mathrm{~K} \text { \% } 9.4 \mathrm{~K} \rightarrow \text { SHARE } \equiv+\text { SAVE } \cdots
$$

Fig 4. Branding by Pewdiepie, this figure was adopted from www.youtube.com on November 27, 2018.

In this video, the branding is performed on the middle segment of the video from the broadcaster. The broadcaster is given a box from the company that sponsors the video. The box reads the name of the company that sponsored the video. The broadcaster also explained in the video description that the video was sponsored by the product shown in Fig 5.

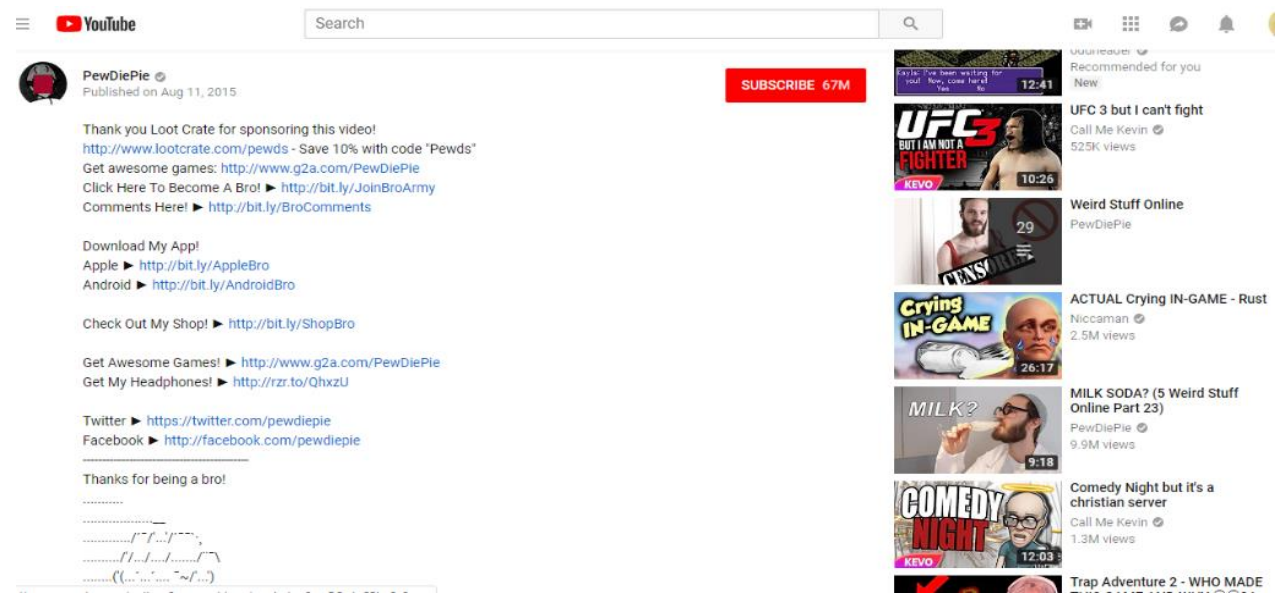

Fig 5. Video Description of Figure, this figure was adopted from www.youtube.com on November 27, 2018.

The broadcaster also includes the website address of the company that sponsored the video to make it easier for the audience to browse the products sold by the company that already introduced by the broadcaster before.

\section{Conclusion}

A company is vital in branding its product to increase sales of its products. The name that is known by the community must be embedded in the head of the community so that the product always becomes familiar among the community. Nowadays the branding is not only done on radio, television, newspapers, magazines only; since the emergence of new media as a medium for communicating companies try to do branding through this new media. One of the efforts of branding in the new media is through an online media broadcaster. Indeed, not all broadcaster can do a good branding, because the broadcaster must first be known in the public eye and have many loyal viewers watching it. Branding should be able to have an impact on product sales because the broadcaster can make the product famous in the public eye. 


\section{References}

[1] Lakshmi, S., \&Muthumani, S. D.: Building Brand Power. In IOP Conference Series:Materials Science and Engineering (Vol. 197, No. 1, p. 012071). IOP Publishing. (2017).

[2] Soegoto, E. S., Marbun, M. A. S., \& Dicky, F.: Building the Design of E-Commerce. In IOP Conference Series: Materials Science and Engineering (Vol. 407, No. 1, p. 012021). IOP Publishing (2018).

[3] Soegoto, E. S.: Entrepreneurship MenjadiPebisnisUlungEdisiRevisi. Elex MediaKomputindo (2014).

[4] Hurriyati, R., \&Rhamdani, F.: Online Consumer Reviews on Using E-Shopping Service of ECommerce. In IOP Conference Series: Materials Science and Engineering (Vol. 180, No. 1, p. 012287). IOP Publishing (2017).

[5] Yunita, I. R., \&Gunawan, W.: The influence of social media to loyalty in an e-commerce. In IOP Conference Series: Materials Science and Engineering (Vol. 420, No. 1, p. 012102). IOP Publishing (2018).

[6] Chung, Christina; Austria, Kristine. Social Media Gratification and Attitude toward Social Media Marketing Messages: A Study of the Effect of Social Media Marketing Messages on Online Shopping Value. Proceedings of the Northeast Business \& Economics Association . p581-586. 6p (2010).

[7] Linda S L A I : Social commerce-e-commerce in the social media context. World Academy of Science. Engineering and Technology, 72(8), pp.39-44 (2010).

[8] Culnan M J, McHugh P J, \& Zubillaga,: J How large US companies can use Twitter and other social media to gain business value. MIS Quarterly Executive, 9(4), pp.6-12 I (2010).

[9] Cho V et.al: An Integrative Framework For Customizations On Staisfication: The Case Of An Online Jewerly Business In China. Journal Of Service And Management, 7(8), pp.165-181 (2014).

[10] Soegoto, E. S., \& Eliana, E.: E-Commerce and Business Social Media Today. In IOP Conference Series: Materials Science and Engineering (Vol. 407, No. 1, p. 012034).

[11] Soegoto, E. S., \& Eliana, E.: E-Commerce and Business Social Media Today. In IOP Conference Series: Materials Science and Engineering (Vol. 407, No. 1, p. 012034). 